\title{
Correction to: What do we lose when machines take the decisions?
}

Thomas Bolander ${ }^{1}$

Published online: 2 March 2020

(c) Springer Science+Business Media, LLC, part of Springer Nature 2020

\section{Correction to: Journal of Management and Governance (2019) 23:849-867 https://doi.org/10.1007/s10997-019-09493-x}

In the original publication, the word "lose" has been inadvertently published as "loose". All occurrences of "loose" should be replaced by "lose". This includes the title, the title headings throughout the paper and 4 occurrences in the introduction. These have been corrected with this Correction.

Publisher's Note Springer Nature remains neutral with regard to jurisdictional claims in published maps and institutional affiliations.

The original article can be found online at https://doi.org/10.1007/s10997-019-09493-x.

Thomas Bolander tobo@dtu.dk

1 DTU Compute, Technical University of Denmark, Lyngby, Denmark 